Even assuming that the accretion of political power in the independent administrative agencies can be curbed short of the oft-predicted dictatorial disaster, what are the implications for the competitively determined price system of the nation? And not the least of the problems raised is whether the regulatory process can continue in a partisan political climate when it has once been given the apparent power to equalize economic opportunity, ${ }^{60}$ albeit in terms of the older notions of application of transportation standards.

\title{
TORT LIABIIITY FOR MISCARRIAGE "CAUSED" BY FRIGHT
}

The field of emotional disturbance has long been a troubled area in the law. Untouched but physically injured plaintiffs have fought a fifty-year battle for redress. They have been blocked mainly by the court's inability to find a causal connection between the negligent act causing their fright and the subsequent physical injury. One class of plaintiffs, however, has had widespread success in the courts. "With few exceptions," Dean Green has said of "fright" cases, "recoveries have been restricted to women, and for the most part pregnant women." I

The early English cases adopted the view that physical harm resulting from the shock caused by another's tortious act was too remote to justify the award of damages. ${ }^{2}$ That the English courts were aware of the weakness of this position is indicated by the slow destruction of the original rule in cases of injury caused by fear for one's own safety, ${ }^{3}$ for the safety of one's husband or children, 4 for passengers, ${ }^{5}$ and, possibly, even for strangers on the highway. ${ }^{6}$

60 The Commission reached its lowest point of respectability and political independence when it departed from the relatively objective transportation standards in favor of the politicoeconomic standards provided by the Hoch-Smith Resolution. Mansfield, op. cit. supra note I 5 , at 165-83; 2 Sharfman, op. cit. supra note Io, at 452-89; Robinson, The Hoch-Smith Resolution and the Future of the Interstate Commerce Commission, 42 Harv. L. Rev. 6ro (I929). Nevertheless, some rejoice in the precedent established in the Class Rate case because the Commission has once more been opened to political pressure. Britt, Tracks to a New Frontier, 36 Survey Graphic 394 (I947).

× Green, "Fright" Cases, 27 Ill. L. Rev. 76I (I933).

2 Victorian Ry. Comm. v. Couitas, 13 A.C. 222 (1888).

3 Dulieu v. White, [rgor] 2 K.B. 669.

4 Hambrook v. Stokes, [x925] I K.B. I4I (mother's fear for her children); Brandon v. Garrett \& Co., Ltd., [1924] I K.B. 548 (fear for husband); Wilkinson v. Downton, [I897] 2 Q.B. 57 (fear for husband).

5 Pugh v. London, Brighton and South Coast Ry., [I896] 2 Q.B. 248 (nervous shock due to signalman's fear for safety of passengers held within the purview of "accident" in an insurance policy).

${ }^{6}$ See Hambrook v. Stokes, [1925] ₹ K.B. I4T, where Atkins, I.J., expressed the opinion that a mere bystander on the highway could obtain damages for shock arising from apprehension or actual sight of injury to a third party. 
The American courts originally displayed the same reluctance to allow recovery in cases of physical illness or injury resulting from fright or other mental disturbance. To date thirty-four states have ruled on the point. Of the twelve states denying recovery, 7 all but three adopted the rule prior to the present century, whereas seventeen of the twenty-one states favoring recovery 8 announced their position during the twentieth century. Those denying recovery have stated four basic reasons: $x$ ) lack of precedent for such a cause of action; 2) since recovery cannot be had for mere fright occasioned by the negligence of another, neither can it be had for physical injuries resulting from fright; 3) the injuries are not "proximately caused"; 4) to allow recovery would result in a flood of non-meritorious litigation in which the damages claimed are speculative and conjectural in character.9

Some courts, in order to permit recovery, have used such expressions as "a touching of the mind," ${ }^{\prime \prime 0}$ or have disguised their findings under the heading of parasitic damages. ${ }^{\text {II }}$ Numerous other exceptions have sprung up around the rule. $^{x 2}$ Courts have been quick to allow recovery where the wrong is wilfully committed, ${ }^{x_{3}}$ where the fright operates externally, as where the frightened person falls and injures himself, ${ }^{x}$ or where there is battery or other physical violence accompanying the shock. ${ }^{\text {.5 }}$ The last exception has been the most important device in alleviating what is considered a harsh rule, and it has been em-

7 Ark., Ind., Ill., Iowa, Ky., Me., Mass., Mo., N.J., N.Y., Ohio, and Pa. deny recovery. Cases collected in Report of the State of New York Law Revision Commission, Act, Recommendation and Study Relating to Liability for Injuries Resulting from Fright or Shock, Legis. Doc. No. 65 (E), at 406 (1936).

${ }^{8}$ States which allow recovery are: Ala., Cal., Ga., Kan., La., Md., Minn., Mont., Neb., N.H., N.C., Ore., R.I., S.C., S.D., Tenn., Tex., Va., Wash., W.Va., and Wis. See Report of the State of New York Law Revision Commission, op. cit. supra note 7, at 406.

- For discussions of these reasons see Comstock v. Wilson, 257 N.Y. 23I, 777 N.E. 43 I (193I) (fear of fabricated claims not justified); Tomis v. Toronto R. Co., 22 Ont. L. Rep. 204 (I9I0) (proximate cause a question of fact); Homans v. Boston El. Ry., I80 Mass. 456, 62 N.E. 747 (IgO2) (mental damage may be foreseen); Bohlen, Studies in the Law of Torts 265 (r926); Magruder, Mental and Emotional Disturbance in the Law of Torts, 49 Harv. L. Rev. I033 (I936); Goodrich, Emotional Disturbance as Legal Damage, 20 Mich. L. Rev. 497 (1922); Hallen, Damages for Physical Injuries Resulting from Fright or Shock, rg Va. L. Rev. 253 (I933).

${ }^{20}$ Lambert v. Brewster, 97 W. Va. r24, I25 S. E. 244 (I924).

Ix Fisher v. Rumler, 239 Mich. 224, 214 N.W. 310 (1927) (false imprisonment); Allan v. Hannaford, I38 Wash. 423, 244 Pac. 700 (1926) (assault).

Iz State of New York Law Revision Commission, op. cit. supra note 7, at 423 et seq.

${ }_{33}$ Rogers v. Williard, $x_{44}$ Ark. 587, 223 S.W. ${ }_{5}$ (1920); Whitsel v. Watts, 98 Kan. 508, 159 Pac. 4 Or (I9r6); Engle v. Simmons, I48 Ala. 92, 4 I So. 1023 (Igo6); Williams v. Underhill, 63 App. Div. 223, 7 I N.Y. Supp. 291 (IgOI); Prieser v. Wielandt, 48 App. Div. 569, 62 N.Y. Supp. 890 (I900); Brownback v. Frailey, 78 Ill. App. 262 (I898).

s4 Chi., R.I., \& P. R. Co. v. Caple, 207 Ark. 52, 179 S.W. 2d I5I (1945); Yashar v. Hakovac, 48 N.Y.S. 2d I28 (City Ct. of N.Y., 1945).

ss Atlanta Hub Co. v. Jones, 47 Ga. App. 778, I7r S.E. 470 (I933); Comstock v. Wilson, 257 N.Y. 23 I, I77 N.E. 43 I (193I). 
ployed to such an extent that the slightest physical impact is sufficient to avoid the operation of the rule..$^{\text {t6 }}$

The use of so many exceptions, some of them absurd, can only be explained by an overpowering reluctance to overturn precedent. The leading tort writers have been unanimous in urging that precedent be podified and a new tort be recognized. ${ }^{17}$ These writers in applying what they thought were modern scientific principles insisted that fright or emotional disturbance may, without any physical cause, have serious physical effects. That this principle-a necessary premise of a rule of law granting recovery in the fright cases--has become almost universally accepted is indicated by the modern majority rule allowing recovery in such cases. Even some courts which continue to deny recovery seem to accept this principle, for they have adopted the position that the only reason for denying recovery is fear of fabricated claims, ${ }^{x 8}$ thus lending weight to the Holmes declaration that the rule denying recovery was "not put as a logical deduction from the general principles of liability in tort, but as a limitation of those principles upon purely practical grounds." ${ }^{2}$ The basis of these decisions was rejected by the New York Law Revision Commission of $193^{620}$ as inconsistent with the principle that for every wrong there should be a remedy, and their practicality was questioned by the Commission's finding that "the number of cases has been largest in those states denying recovery, due to the many exceptions grafted on the harsh rule."2r

The writers who strove to bring the law abreast of "modern" medical knowledge found it increasingly difficult to reconcile their views with the latest medical discoveries. Bohlen, speaking at the turn of the century, was able to say positively that "In cases of injury to person the connection between the original inciting cause and the final physical deterioration is now capable of accurate diagnosis and proof by medical testimony." "2zoodrich some twenty years later

${ }^{26}$ Cf. Morton v. Stack, I 22 Ohio St. II5, I7O N.E. 869 (I930) (inhalation of smoke); Porter v. Delaware, I. \& W. R. Co., 73 N.J.L. 405,63 Atl. 860 (Ig06) (dust in the eyes); Homans v. Boston Elev. R. Co., I80 Mass. 456, 62 N.E. 737 (Igo2) (slight bump against seat); Spade v. Lynn \& Boston R. Co., I72 Mass. 488, 52 N.E. 747 (I898) (slight blow).

17 Magruder, Mental and Emotional Disturbance in the Law of Torts, 49 Harv. L. Rev. ro33 (1936); Hallen, Damages for Physical Injuries Resulting from Fright or Shock, Ig Va. L. Rev. 253 (r933); Green, "Fright" Cases, 27 Ill. L. Rev. 76r, 873 (1933); Bohlen and Polikoff, Liability in New York for the Physical Consequences of Emotional Disturbance, $32 \mathrm{Col}$. $\mathrm{L}$. Rev. 409 (1932); Bohlen, Studies in the Law of Torts 252 (x926); Goodrich, Emotional Disturbance as Legal Damage, 20 Mich. L. Rev. 497 (I922); Prosser, Torts § 34 (I94I).

${ }^{18}$ Comstock v. Wilson, 257 N.Y. 23I, I77 N.E. 43I (I93I). "It may be said with some confidence that Comstock v. Wilson does recognize that the only reason for denying recovery is fear of fabricated claims." Bohlen and Polikoff, Liability in New York for the Physical Consequences of Emotional Disturbance, 32 Col. L. Rev. 409, 447 (1932).

${ }^{29}$ Holmes, C. J., in Smith v. Postal Telegraph Cable Co. of Mass., I74 Mass. 576, 577, 55 N.E. 380 (1899).

${ }^{20}$ State of New York Law Revision Commission, op. cit. supra note 7, at 422.

2x mid., at $42 \mathrm{x}$.

${ }^{22}$ Bohlen, Right To Recover for Injury Resulting from Negligence without Impact, 4 I Am. Law Reg. (N.S.) I4I, I50 (IgO2). 
was able only to "look with interest and sympathy ... . for more light from the scientist," ${ }^{23}$ and Hallen, even more recently, concluded that although there is no proof of a causal connection "certainly no rule of logic forbids the extension of liability to include this situation." ${ }_{24}$

It is rronic that, when the English courts and a majority of the American courts have become convinced that physical injuries may stem from emotional disturbances, medical science has demonstrated in the largest category of these cases-miscarriages - that there is no basis whatsoever for allowing recovery. Obstetrical research has resulted in the medical view that fright cannot cause abortion. ${ }^{25}$

Obstetricians believe that predisposing causes-abnormalities or defects found either in the fetus, the mother, or the father's spermatozoa ${ }^{26}-$ must be held responsible for all abortions except where direct violence has been inflicted on the uterus. Where such a predisposition exists, the pregnancy is endangered, and only extreme caution on the part of the woman will bring it to term. In a study of 1,027 spontaneous abortions ${ }^{27}$ over a five-year period in the Boston area, Hertig and Edmonds found internal defects in all but 4 per cent of the cases. $^{28}$ And they suspected criminal abortion in the unsolved 4 per cent. Spontaneous abortions occur most often in the second and third months of pregnancy, and adequate examination usually reveals a predisposing cause..$^{29}$

Although in only half of the cases of recurrent abortion ${ }^{30}$ can a direct, internal cause be definitely assigned, only about I per cent of the total number of abortions are of this type. ${ }^{3 x}$ The medical world has concluded that where no such cause is found, transient endocrine or metabolic disturbances are active..$^{32}$ An

${ }^{23}$ Goodrich, Emotional Disturbance as Legal Damage, 20 Mich. L. Rev. 497, 508 (1922).

${ }^{24}$ Hallen, Damages for Physical Injuries Resulting from Fright or Shock, Ig Va. L. Rev. 253,270 (I933).

${ }^{25}$ Abortion is the medical term for miscarriage and includes all interruptions of pregnancy occurring before the fetus is capable of extra-uterine existence.

${ }^{26}$ The most important predisposing causes are the defective development of the embryo and diseases and abnormalities of the maternal uterine membranes in which the fetus is implanted. Williams, Obstetrics 809 (Stander's 8 th ed., I94r).

${ }^{27}$ First abortions and abortions that have been preceded by a normal pregnancy are characterized medically as "spontaneous."

${ }^{28}$ Hertig and Edmonds, Genesis of Hydatidiform Mole, 30 Archives of Pathology 260 265-68 (1940).

29 Ibid., at 265 .

${ }^{30}$ The recurrent cause case is that of the habitual aborter. From a statistical standpoint the presence of a recurrent factor may be inferred with reasonable certainty after the occurrence of three successive pregnancy failures. Malpas, A Study of Abortion Sequences, 45 Journal of Obstetrics and Gynecology of the British Empire 932 (1938).

${ }^{3 x}$ Ibid., at 947 .

32 Mason, Sex Hormone Factor in Recurrent Abortion and Sterility, 35 American Journal of Obstetrics \& Gynecology 559 (1938). 
outstanding authority in.obstetrics asserts that, unless a force has been applied to the uterus directly, it must be assumed that one of the predisposing causes is active. 33 The natural tenacity of non-defective fetal life precludes a random cause other than direct touching of the fetus from producing a miscarriage.

The thesis that every miscarriage must have a predisposing cause gains support with every report from those engaged in research within the metabolic and endocrine fields as related to fetal life. ${ }^{34}$ It is clear from controlled experiments that an endocrine disturbance may cause abortion, ${ }^{35}$ though it remains diffcult to discover, in retrospect, which of the multitude of factors has been responsible for the abortion. Practicality of measurement of endocrine and metabolic factors in clinical medicine has not kept pace with the discovery of their presence and activity in experimental medicine. Thus the inability to account definitely for about 4 per cent of the total number of abortions does not reflect the state of knowledge that has resulted from controlled experiments. Even though a predisposing cause cannot be discovered in any given case, it may be postulated with almost absolute certainty.

The inescapable conclusion from the medical evidence is that fright is not a cause of abortion. Research has disclosed no known process, method, or route by which a mental state may transmit a force causing injury to, or the expulsion of, a fetus. Psychiatrists are aware of the acute mental tension in most unmarried mothers. Yet the incidence of abortion is no greater in this group than in any other group of mothers. ${ }^{36} \mathrm{It}$ is significant that experiments conducted with pregnant animals, such as monkeys and cats, in an effort to produce abortion by shocks calculated to upset their nervous systems, all have failed. ${ }^{37} \mathrm{Medical}$ authorities deny that fright acts even as a "precipitating" agent setting a predisposing cause in motion. A leading authority concludes that the occurrence of abortion after a fright is pure coincidence..$^{38}$

In the face of the overwhelming weight of leading medical opinion, plaintiffs should be required to produce more than circumstantial evidence in order to sustain the burden of proving that the miscarriage resulted from fright. As the law is today, busses cannot jolt, trains cannot jerk, and men cannot shout or have automobile collisions in front of the predisposed, pregnant woman. It seems unreasonable to ask society to assume this degree of care. Interested as society must be in the unborn, liability would appear to place too great a burden upon the everyday activities of a turbulent civilization.

33 DeLee and Greenhill, The Principles and Practice of Obstetrics 422 (8th ed., I943).

${ }^{34}$ MacGregor and Steward, An Investigation of Prozesterone, 46 Journal of Obstetrics and Gynecology of the British Empire 857 (I939).

35 Allen, Physiology of the Ovaries, in American Medical Association Council on Pharmacy and Chemistry, Glandular Physiology and Therapy 143 et seq. (1942).

${ }^{36}$ Private communication, Dr. M. Edward Davis, Professor of Obstetrics and Gynecology, University of Chicago (r947).

37 Ibid. $\quad$ $\quad 3^{8}$ Ibid. 